\title{
The Relationship Between Social Work and Social Pedagogy - Similarities in Theory and Profession from a German Perspective
}

\author{
Klaus Kraimer $^{1}$ \\ Lena Altmeyer ${ }^{2}$
}

\author{
Contacts to authors \\ ${ }^{1,2}$ University of Applied Sciences, \\ Faculty of Social Sciences, \\ Rastpfuhl 12a, \\ D-66113 Saarbrücken \\ klaus.kraimer@htw-saarland.de \\ lena.altmeyer@htwsaar.de
}

\section{Kontakty na autory}

1,2 Univerzita aplikovaných studií, Fakulta sociálních věd, Rastpfuhl 12a, D-66113 Saarbrücken klaus.kraimer@htw-saarland.de lena.altmeyer@htwsaar.de

Copyright (C) 2016 by authors and publisher TBU in Zlín. This work is licensed under the Creative Commons Attribution International License (CC BY).

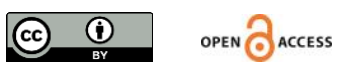

\begin{abstract}
The contribution focuses on similarities of social work and social pedagogy in the German-speaking area and with relation or reference to International classic authors such as Mary E. Richmond and Alice Salomon. The similarities that were elaborated point in particular to a concentration on "education to maturity" (Adorno, 1969), which should be indispensable in both theoretical traditions. The article is a short version of the study Case Reconstructive Social work developed elsewhere (Kraimer, 2000, 2014) which includes the social-pedagogical perspective as an integral part.
\end{abstract}

Keywords: social work, social pedagogy, professional work, vicariously coping with crisis, qualitative respectively reconstructive social research

\section{Vztah mezi sociální pedagogikou a sociální prací - teoretické a profesní podobnosti z německé perspektivy}

\begin{abstract}
Abstrakt: Příspěvek se zaměřuje na podobnosti mezi sociální prací a sociální pedagogikou v německy mluvící oblasti a na jejich vztah $\mathrm{k}$ mezinárodně uznávaným autorům jako jsou Mary E. Richmond a Alice Salomon či odkazy na tyto autory. Podobnosti, které jsou rozpracovány, poukazují v první řadě na důležitost „vzdělávání k dospívání" (Adorno 1969), které je v obou teoretických tradicích nepostradatelné. Príspěvek je zkrácenou verzí studie Fallrekonstruktive Soziale Arbeit (Rekonstrukce případu jakožto metoda sociální práce) publikované jinde (Kraimer, 2000, 2014) která zahrnuje sociálně-pedagogickou perspektivu jako svoji nedělitelnou část.
\end{abstract}

Klíčová slova: sociální práce, sociální pedagogika, profesionální práce, zprostředkované zvládání krizí, kvalitativní respektive rekonstrukčně sociální výzkum

\section{Introduction}

"Vicariously coping with crisis because these activities... are about dealing with the crises of others, be it specific other persons or groups subject to sovereign collectivisation, or even future generations" (Oevermann, 2009, p. 114). 
This contribution aims at providing a brief insight into the relationship between social pedagogy and social work. In the German-speaking area, the term "Social Work" is by now used as a heading for both social work and social pedagogy ${ }^{1}$. The focus is on both the historical genesis (Section 2) and on current research and treatment methods which are presented based on their characteristics (Section 3). The explanations will look at case-oriented - in contrast to classificatory - research and treatment methods. The two theoretical traditions discussed (social work and social pedagogy) have similarities particularly in terms of their case orientation. The fourth part - largely in the shape of a thesis - deals with disciplinary and profession-related bases for "case-reconstructive Social Work". A casereconstructive process implies the establishment or re-establishment of an autonomous life practice. Pedagogy and Social Work professionals should enable this e.g., in nurseries or at schools and as such, early on in a person's life. Autonomy must be re-established in a person's life where this has been lost or become impossible and should continue throughout their life. Collective disasters (epidemics, wars) and human tragedies accompanying these are examples of situations in which a person's autonomy can suffer damage or destruction. This can also be caused by political and social deficiencies, such as socialising interaction if deficient child-raising and educational processes prevail.

Overall, the aim is to present a current model that we consider to be internationally forward-looking: Social Work as vicarious coping with crisis, in which social pedagogy and social work professionals work in the hybrid work relationships of social aids to perceive social activities (such as in special needs and curative pedagogy or in adult education) in order to estimate and promote the autonomy options of their service users. As a result, we believe that "case-reconstructive Social Work" constitutes a comprehensive model for designing Social Work because this offers support in coping with crisis for different ages. "Case-reconstructive Social Work" relates to three dimensions of professional action, which Oevermann (2009, p. 120) developed in the context of his professionalisation research. These are the dimensions of: Somato-psycho-social integrity, law and justice based on applicable laws, and methodically explicit verification of applicability in notional and sensual perception (science and art) (cf. Section 4).

At the moment, the current debate in the Federal Republic of Germany only reflects these perspectives rudimentarily. For instance - in the context of the primary social work discourse at (specialised) universities - the socio-political development characterised by the neoliberal restructuring of macrosocial conflicts and crises is increasingly a topic of discussions (cf. e.g., the agenda of the 9th Federal Congress for Social Work in Darmstadt; 30 September to 2 October 2015). The focus of educational science, which continues to dominate the socio-pedagogical discourse at universities (cf. the topic Spaces for education. Spaces of education - 25th DGfE ${ }^{2}$ Congress 2016 at the University of Kassel), is currently on education. Discussions primarily deal with how education is granted or withdrawn, as well as with how the rooms used for education are or could be designed and what an optimal modulation of the cultures of education and child-raising could look like within the given socio-spatial structures and the conditions for designing public education and child-raising in social institutions.

\section{Short historical outline: Social Work, social work and social pedagogy}

From the 1960s, professional practice of social work and social pedagogy in Germany - nowadays frequently combined under the heading of Social Work - undergoes a quantitative expansion (across its life span and from cradle to grave) as well as a qualitative differentiation (such as school social work). This applies increasingly from the 1980s, especially in the field of social work and social pedagogy services, resulting in a summary of the formerly separate education and work areas. Historically speaking, both the development of social work and that of social pedagogy can be

1 In the essay at hand the term "Social Work" when used for the german term "Soziale Arbeit" is capitalized. When used for the german term "Sozialarbeit" it is not capitalized.

2 German Society for Educational Science (DGfE). 
interpreted as the systematisation of honorary and professional activities on an ethical basis - initial similarities in the two traditions also become apparent here. Nevertheless, the two traditions have a different focus as regards content. In social pedagogy, the reconstruction of educational and childraising crises is significant, whereas social work looks at the reconstruction of crises resulting from poverty and hardship. Little by little, based on the anthropological fact that humans are dependent on help in a crisis, methodical models arise in the context of historically grown, social reactions which demonstrate increasing efforts towards professionalism. This is true of both theoretical traditions. The aim here is to examine these different threads in more detail from a case-reconstructive perspective by way of example - for further perspectives on the genesis of social pedagogy see Reyer (2002), Dollinger (2006) and of social work see Lüssi (1991); for the genesis of Social Work see Engelke (1992).

The origins of traditional social work are identified in the "poor relief by 19th century communities, free acts of love and aid work, the... feminist movement and... welfare" (Bock, 1986, p. 746). Key figures include Mary Richmond, Jane Addams and Alice Salomon. They trigger a collective professionalisation, specifically because they establish connections with the classics of philosophy, sociology and empirical social research, which are significant for the methodical context of theory and practice. As a result, conventional social work is based primarily on sociological, socio-political and legal knowledge, making reference to social connections, social co-habitation, social acts or regulation by written norms and laws as well as opportunities for the provision of social aid. Social work is centred around public welfare and social aid, which in the Republic of Germany is organised primarily where private care or care by the family is disrupted or unavailable based on the principle of subsidiarity; as a regulatory factor, this principle aims to characterise the need for, provision or refusal of aid alongside the possibility of a person coping independently. At the heart of this tradition are efforts to humanise living conditions through practical social work and its disciplinary reflection in relation to principles such as a focus on the common good, social justice or opportunities for everyone to participate in property, culture, child-raising and education. The current "social security" system used in many countries in Europe - albeit applied very differently in each country - basically follows this idea.

In contrast to social work in the traditional sense, social pedagogy focuses primarily on the pedagogic body of thought and - more or less explicitly - follows a basic thought process based on theories of education. This corresponds to the body of knowledge of general or systematic pedagogy, and above all in pedagogic anthropology. This body of knowledge largely relates to matters of child-raising and on pedagogical action as well as on theoretical statements about education, child-raising and learning processes. Particularly Klaus Mollenhauer, Hans Thiersch and Burkhard Müller form part of this tradition of social pedagogy - along the lines of a democratisation of living conditions - and in favour of a more academic approach towards the discipline and profession now called Social Work. These authors are turning hermeneutic and phenomenological approaches with connections to earlier traditions into integral parts of the development of theories, practical research and practical design relating to the two original traditions.

For instance, Thiersch is clearly speaking up in favour of a pedagogic focus of Social Work. In 1959, Mollenhauer also suggests pedagogy, and more specifically social pedagogy, as the sole "basic theoretical reflection" for Social Work as a whole. Mollenhauer in a later paper: "What we summarily assign to the sphere of social pedagogy/social work is in fact a highly heterogeneous field of actions, measures and institutions. Only part of this can be related to pedagogy" (Mollenhauer, 1988, p. 54). With this, Mollenhauer opens up the opportunity of a re-alignment, which is expressed in today's use of the term Social Work. Niemeyer agrees: "For a long time, the term social pedagogy was closely linked to the pedagogic knowledge base and argumentation culture and, if we focus on the theoretical tradition for which Nohl has provided evidence, can be interpreted as finding its origins in reform pedagogy and the German Civic Youth Movement. By contrast, social work - respectively 
Social Work - is founded in the tradition of poverty relief and its origins lie in the civic feminist movement" (Niemeyer, 2012, p. 146).

E.g., the ground-breaking compendium by Otto and Thiersch (2011) shows that nowadays, the term Social Work is used to denote both social work and social pedagogy: Whereas the titles of the first three editions (1984 with Hanns Eyerth, 2001, 2005) include the terms social work and social pedagogy, the title of the fourth edition (2011; 5th edition 2014) only uses the term Social Work. "An approximation in terms of content is also apparent in that phrases such as 'social pedagogy/social work' are frequently used as if they are synonyms. Even universities, which Nohl - during his time in Göttingen in the Weimar epoch - still recommended should emphasize social pedagogy as a subdiscipline of pedagogy to distinguish it from the 'science of welfare' (Salomon) taught at Women's Social Colleges, nowadays often combine these two terms" (Niemeyer, 2012, p. 147). In terms of the historic development of professional associations, it becomes apparent that the German Professional Association for Social Work (DBSH) founded in 1995 combined the then existing professional associations DBS (German Professional Association for social work) and BSH (German Professional Association for Social workers/Social pedagogues, Curative Pedagogues - United Representation of Social Pedagogy Professions e. V.). As such, the generic term Social Work also takes hold in this area.

As an interim conclusion, it can be stated that, while social pedagogy and social work developed as distinct entities, today they have merged into one research and behavioural framework as Social Work. This can e.g., be demonstrated as follows: When Social Work looks at the migration crisis, it discusses macro-societal questions in the context of socio-scientific knowledge; if the topic is education and raising the next generation, then the themes of education sciences are prioritised. The two scientific reference systems act as two drives of one hybrid knowledge and behavioural framework (cf. Schütze, 2014). As a result, this paper takes the approach that, given the current heterogeneity and hybridity of Social Work, some of these areas cannot be substantiated in terms of either pedagogy or education science.

\section{Case reconstruction as a model for Social Work research and practice - between abstraction and reification}

"Case structures are always case structures of a historically concrete life practice... and as such contradictory units of decision-making pressure and justification obligations as well as centres for coping with crisis" (Oevermann, 2000, p. 148).

Today, Social Work - as a community of the two previously separate areas of social pedagogy and social work - is basically dominated by two types of methods: They are research and behavioural methods which have developed over time with more or less reference to each other and which currently, within the meaning of habit ${ }^{3}$ creation (see Figure 1), are essential for ensuring the longterm autonomy of Social Work as research and behavioural practice. In order to understand this connection, a distinction must first be made between "abstraction" (theory) and "reification" (practice): This differentiation is required at all times in this regard in order to clearly underline what can and should be achieved in each case so that an amalgamation that might damage the purity of the process can be avoided. Research methods - using the mode of abstraction - require an unconditional relief from the tasks of concrete practice. In principle, this is about developing

\footnotetext{
According to Bourdieu, habit describes the interplay of routines, habitualities and attitudes characterising a person's manner. "The cognitive structures used by social actors in their practical cognition are incorporated social structures," which "work beyond consciousness and discursive thinking" (Bourdieu, 1984, p. 730). In his revised professionalisation theory, Oevermann describes a habit formation which ideally employs the components of hermeneutic case understanding and theoretical understanding to form a routine in professionalised practice applying the logic of vicarious coping with crisis (1996) (professional habit).
} 
scientific findings which are brought to bear independently of political or institutional expectations. In this respect, scientific practice is free from the pressures of expectations, time or results in order to be able to research the "matter itself" without being patronised. The aim is to develop theoretical models, ideally through a prior reconstruction of practice, which operate in the reality of practice and which can be taught to those studying the subject in the course of their studies - such as in research workshops (cf. Kraimer \& Wyssen-Kaufmann, 2012) so that the mentioned habit creation becomes possible and is facilitated. The methods used are primarily research processes based on reconstruction logic and hermeneutically inspired case work.

Habit creation as mediation instance between
$\begin{gathered}\text { Scientific Knowledge (competence of } \\ \text { theoretical understanding) }\end{gathered}$
$\begin{gathered}\text { To understand scientific findings } \\ \text { (interpretation options of the } \\ \text { professional as knowledge which can } \\ \text { be generalized, extensive } \\ \text { development of models) } \\ \begin{array}{c}\text { (competence of case understanding) } \\ \text { Research methods in the insight } \\ \text { finding mode }\end{array} \\ \text { practice (client difficulties in their life } \\ \text { practice as "individual case", } \\ \text { e.g., disadvantage, illness) }\end{gathered}$
Action methods in vicarious coping
with crisis mode

\section{Tensions can not be resolved technically}

Figure 1 Habit creation in discipline and profession (Kraimer, 2014, p. 19)

Professional practice experiences time pressure and as such focuses on dealing with practical life problems. As a result, methods for action - using the mode of reification - require the person acting in professional practice to find relief by accessing methods which have previously been founded in the discipline and whose approach has been habitualised. In principle, this is about practising vicarious coping with crisis applying the knowledge basis of academic studies. The aim is to create a work alliance to (re-)establish autonomous life practice. Accordingly, professional practice is bound by the ethics of action, the disciplinary empiricism of research ethics.

The process of case reconstruction can be useful for both method types. The process of case reconstruction, which constitutes a theory of art, is aimed at revealing case-specific social connections in terms of meaning and actions, which are embedded in the structural system and system of rules. This makes it possible to examine the relevant materials of expression - corresponding primarily to the context of social aids, social prevention or social services - in relation to their structural logic (research) and then apply this to the conceptualisation of an intervention (practice), e.g., as vicarious coping with crisis or as biographical guidance.

Ulrich Oevermann (2000) introduces the method of sequence analysis, a process which can be used to determine the analytical difference between the varied options of a given empirical reality and the actual choices made (as a result of decisions). A distinction must be made between two characteristic dimensions (parameters). The dimensions presented as creation and selection parameters are:

(1) Rules for creating meaning, which create possible connections in the relevant sequences (thought-experimental generation of choices).

(2) The totality of options available as a togetherness necessitating a choice. 


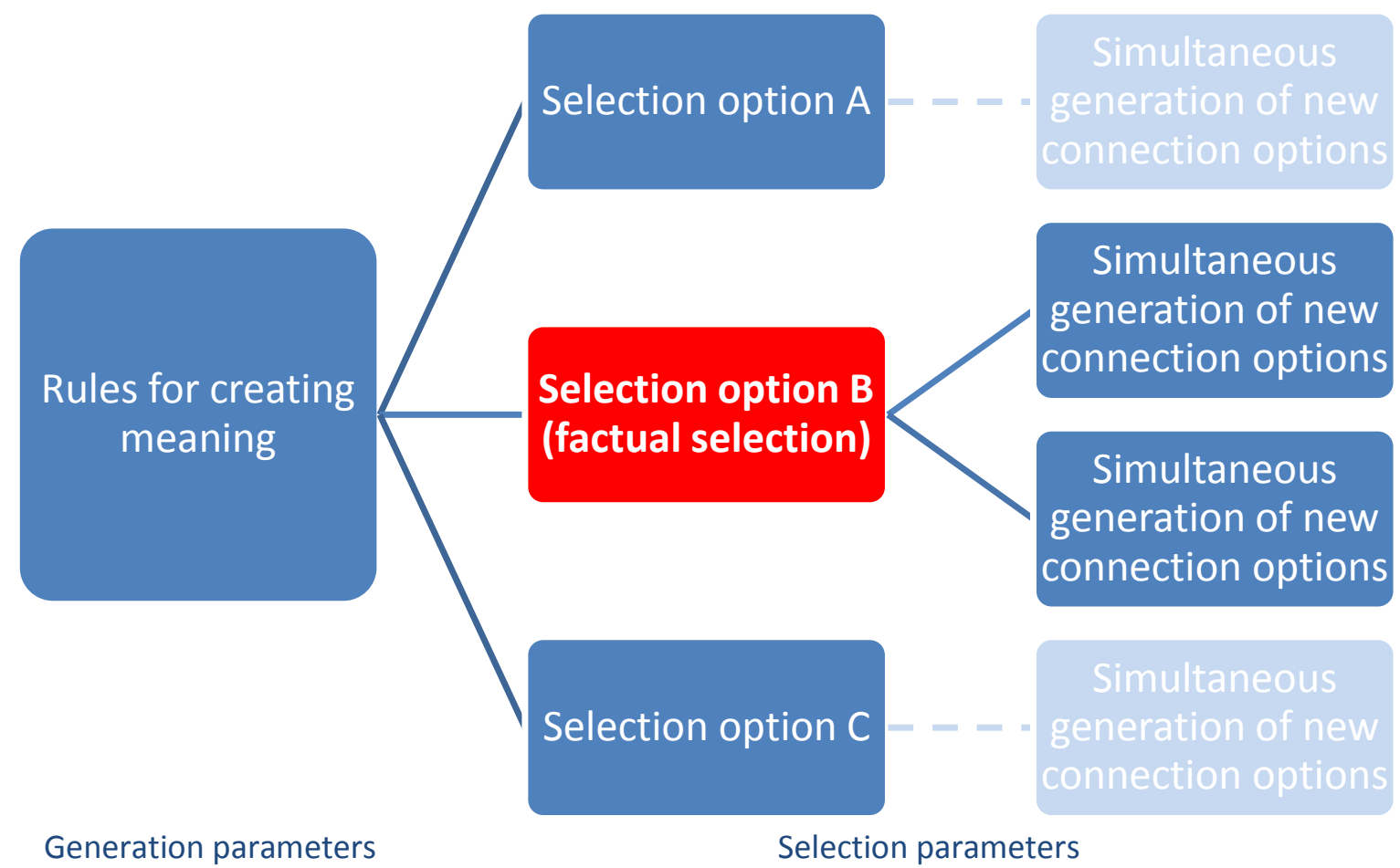

Figure 2 Generation and selection parameters, own presentation based on Oevermann (2000)

The sequence analysis method follows the sequential nature of life. As such, it is based around the idea that human action is structured sequentially by rules. "Every apparently single action is sequentially linked to a previous action within the meaning of a well-formed, rule-like connection. In turn, it opens up scope for well-formed, regular connections" (Oevermann, 2000, p. 64). The reconstruction of the material of expression is based on this.

The essential characteristic of case reconstruction is the approach that a case to be examined is analysed in relation to its differentiation by practical decisions and based on objective data to identify latent and manifest structures of meaning.

The aim of the methodically controlled reconstruction process is to reveal the origins of a case as structural genesis. This is achieved by formulating key structural characteristics, which can be set out in the shape of case structural hypotheses (cf. in detail: Kraimer, 2014; Oevermann, 2000). As a result of a case reconstruction, a scientific object can be delineated explicitly and identifiably in its historical development and in a characteristic, definable shape and rule-relatedness. This brings about the essential difference compared to case descriptions, case studies or procedures whose aim is to analyse content or to categorise, which merely allocated individual phenomena by applying subsumption logic (normally terms or categories classified in advance) and which are missing a dimension which unlocks the matter itself. In contrast to quantifying research (which applies subsumption logic), an empirical generalisation is not the aim - instead, a structural generalisation according to the methodology of objective hermeneutics is intended. A case reconstruction shows how practice/a case operates or proceeds from a structural perspective - different from, or even adding to, the presentation of the case history by the case itself or the person presenting the case or the biography. Practice can also become involved in the course and on the basis of a case reconstruction so as to reveal alternative options for action or develop suggestions for vicarious coping with crisis/biographical consultations, as intended as part of Social Diagnostics. However, above all, professional practice can be designed as case-reconstructive to begin with.

The reconstructive process can be used to find types of readings (using thought experiments) which help to reconstruct the choice and reasoning of decisions. The aim is to read a text artistically and creatively in order to identify the structure of meaning contained within it - no additional 
meaning should be "superimposed" on the text. Oevermann has developed principles of interpretation for just this purpose (cf. Oevermann, 2000): Absence of context, literalness, economy, totality/extensivity, and sequentiality. The meaning is stored within a text, it is discovered sequentially by different types of readings and finally it is revealed in its structuredness: Early on in an interpretation, many different types of readings are still possible; in the course of the reconstruction, the number reduces as inapplicable types of readings are excluded until the case structure becomes clear.

\section{$4 \quad$ Disciplinary and profession-related basis of Social Work: Vicariously coping with crisis as a model of professional practice}

The model of vicarious coping with crisis can be said to constitute a basis for Social Work as a theoretical discipline and a professionalised activity as far as research on autonomy options and the establishment or re-establishment of a somato-psycho-social integrity is concerned. The aim is essentially to relate professional action in Social Work to the following dimensions in this context:

Table 1

Functional areas of focus of professionalization (Oevermann, 2009, p. 120)

\begin{tabular}{|c|c|c|c|c|c|}
\hline & Functional focus & Client & $\begin{array}{l}\text { Central type of } \\
\text { practice }\end{array}$ & $\begin{array}{l}\text { Dominant type } \\
\text { of crisis }\end{array}$ & $\begin{array}{l}\text { Mode of } \\
\text { experience }\end{array}$ \\
\hline (1) & $\begin{array}{l}\text { somato-psycho- } \\
\text { social integrity }\end{array}$ & $\begin{array}{l}\text { particular life } \\
\text { practice }\end{array}$ & work cooperation & traumatic crisis & $\begin{array}{l}\text { experience o } \\
\text { nature } \\
\text { and body }\end{array}$ \\
\hline$(2)$ & $\begin{array}{l}\text { law and justice } \\
\text { based on } \\
\text { applicable laws }\end{array}$ & $\begin{array}{l}\text { community } \\
\text { based on law }\end{array}$ & $\begin{array}{l}\text { processes based on } \\
\text { formal/rational rules }\end{array}$ & $\begin{array}{l}\text { crisis of } \\
\text { decision-making }\end{array}$ & $\begin{array}{l}\text { religious } \\
\text { experience }\end{array}$ \\
\hline (3) & $\begin{array}{l}\text { methodically } \\
\text { explicit } \\
\text { verification of } \\
\text { applicability in } \\
\text { notional and } \\
\text { sensual } \\
\text { perception } \\
\text { (science and art) }\end{array}$ & $\begin{array}{l}\text { universe of } \\
\text { discourse } \\
\text { (represented by } \\
\text { the sovereign } \\
\text { community } \\
\text { based on law) }\end{array}$ & $\begin{array}{l}\text { methodical criticism } \\
\text { of deliberative } \\
\text { discourse (logic of } \\
\text { the better argument } \\
\text { and suggestiveness } \\
\text { of sensual presence }\end{array}$ & $\begin{array}{l}\text { crisis due to } \\
\text { inactivity }\end{array}$ & $\begin{array}{l}\text { aesthetic } \\
\text { experience }\end{array}$ \\
\hline
\end{tabular}

Below, three theses will be presented for this context, which could lead a future development of social work as a discipline and a profession along the lines of a case-reconstructive process:

Thesis 1: The project of professionalising "case-reconstructive Social Work" must be designed based on the principle of vicarious coping with crisis.

"At the heart of our version of a professionalisation theory is the simple thesis that all professional practice in need of professionalisation basically deals with the tasks of vicarious coping with crisis for a client based on explicitly methodical knowledge, and that the manifest professional state of these professions is linked to the perception of such vicarious coping with crisis" (Oevermann, 2013, p. 119).

The regulating idea of vicarious coping with crisis, whose aim is to construct an autonomous life practice, determines action for "case-reconstructive Social Work". 
Vicarious coping with crisis ${ }^{4}$ constitutes a regulating principle which guides the professional's action. In the course of life, this is expressed in different ways and qualities in the support to cope with the crises of appropriation, loss and regaining of autonomy. In this context, we must also ask about the viability dynamics of a specific life practice - assuming a professional intervention - which can be developed by reconstructing the individual history in interacting with professionally offered support in an institutional context. Vicarious coping with crisis is based on "case-reconstructive Social Work" action by a social lawyer. As a representative of those objectively or subjectively in need of help, it has a duty to balance out any impairments of a humane life and to obtain the funds required for this purpose and allocated by the legislator (cf. Oevermann, 2009).

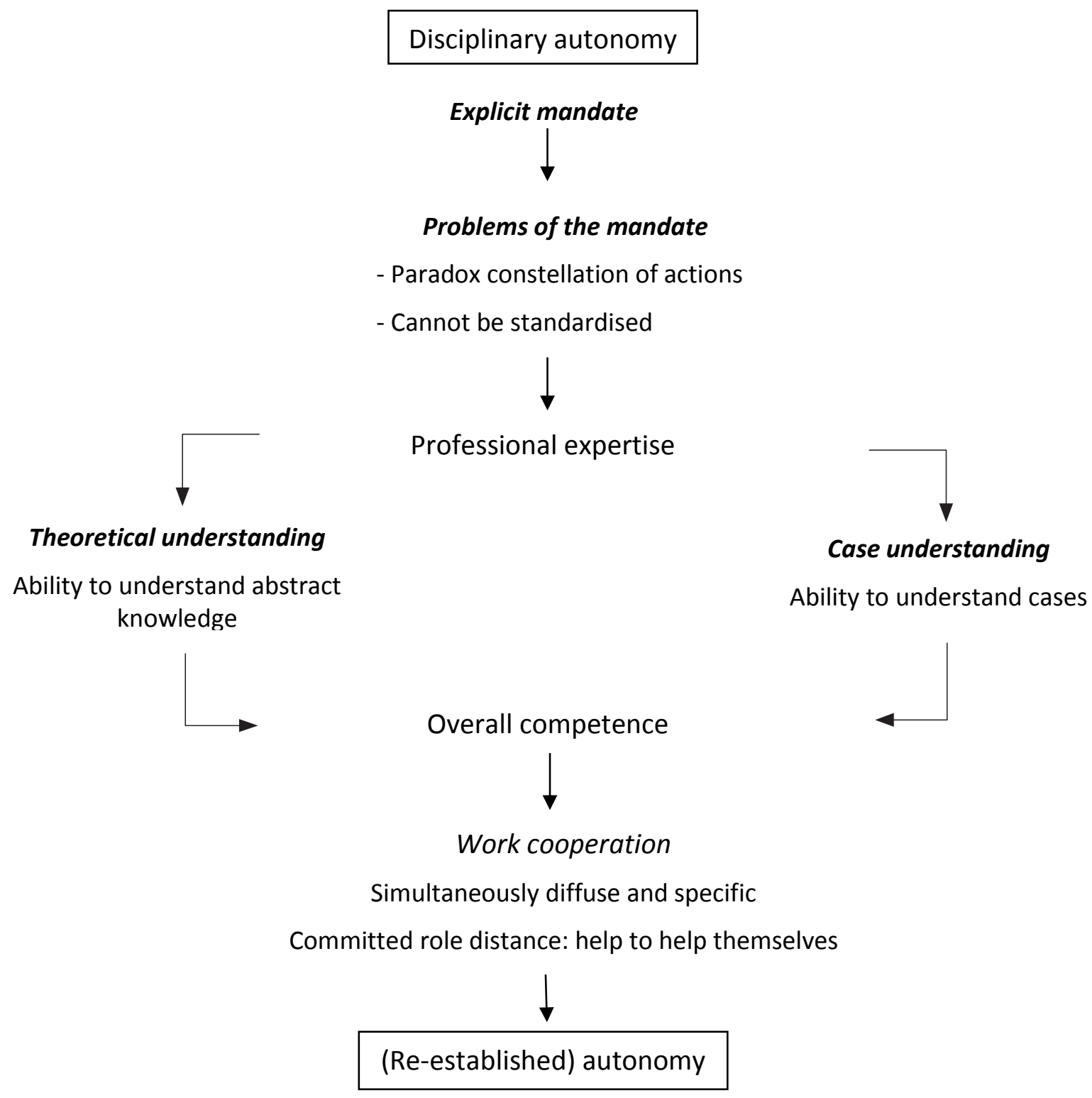

Figure 3 The logic of vicarious coping with crisis (Kraimer, 2012, p. 92)

A client deficient in autonomy (see table 2) requires a type of help provided based on a mandate which ensures the kind of expertise that does not lead to a de-autonomisation of the client but instead contributes to the identification of options and their realisation for an autonomous life.

4 By way of example for this model, cf. the study by Czarny and Marks (2015) and the paper by Kraimer and Altmeyer (2016). 
The habit formation of the aide professionalised in this manner enables a work cooperation to be established, enabling a factual dealing with the problem through help but not through control. It is extremely important in this context for intervention practice which becomes effective in the work cooperation to always remain aware of a realistic estimate of the client's autonomy options and mobilisation. This assumes an awareness of the conditions of an autonomous life practice and of the term "free action". The conceptualisation of a work cooperation requires the mentioned knowledge as well as an ideal model based on an awareness of the theoretical foundations. Both of these must be acquired during studies, as does knowledge of potential obstacles to such a cooperation (cf. ibid).

Table 2

Theoretical process based on Liebermann and Loer (2009)

\begin{tabular}{|c|c|c|c|}
\hline Phase & Client & Professional & Objective \\
\hline Initial phase & $\begin{array}{l}\text { Client must realise } \\
\text { that help is needed } \\
\text { (psychological strain) }\end{array}$ & Attitude of waiting & $\begin{array}{l}\text { Mutual } \\
\text { communication }\end{array}$ \\
\hline $\begin{array}{l}\text { Anamnestic-diagnostic } \\
\text { phase }\end{array}$ & $\begin{array}{l}\text { Reveals his need for } \\
\text { help }\end{array}$ & $\begin{array}{l}\text { Anamnesis and } \\
\text { diagnosis }\end{array}$ & $\begin{array}{l}\text { Clarity about the crisis } \\
\text { to be resolved } \\
\text { together }\end{array}$ \\
\hline Constellation phase & $\begin{array}{l}\text { Contributes potential } \\
\text { for crisis } \\
\text { resolution/realises } \\
\text { own options }\end{array}$ & $\begin{array}{l}\text { Professional } \\
\text { maieutically promotes } \\
\text { the potential }\end{array}$ & $\begin{array}{l}\text { Verbal identification of } \\
\text { the crisis to open up } \\
\text { scope for a solution }\end{array}$ \\
\hline Modelling phase & $\begin{array}{l}\text { Releasing } \\
\text { potential/move to } \\
\text { independent crisis } \\
\text { resolution }\end{array}$ & $\begin{array}{l}\text { Promoting the client's } \\
\text { autonomy }\end{array}$ & $\begin{array}{l}\text { Joint modelling of } \\
\text { crisis resolution }\end{array}$ \\
\hline Conclusion phase & $\begin{array}{l}\text { Client acceptance of } \\
\text { responsibility }\end{array}$ & $\begin{array}{l}\text { Recognition of } \\
\text { autonomy to be re- } \\
\text { established }\end{array}$ & $\begin{array}{l}\text { Autonomy of life } \\
\text { practice }\end{array}$ \\
\hline
\end{tabular}

The process shown in table 2 shows an organisational model which constitutes an ideal process. This process might be hampered in practice. The difficulties in contrast to the model developed by Liebermann and Loer (2009) with reference to Oevermann can be found primarily in the specifics of the type of social work practice so far (cf. Oevermann, 2009; Wigger, 2013). To summarise, these are primarily the following problems:

- The problem of incompatibility between help and control.

- The problem of the stigmatising effect of help.

- The problem of a (frequent) lack of voluntary involvement.

For the latter reason alone, initiating a work cooperation - fundamentally based on voluntary involvement - is made more difficult largely due to social control and help, creating a potential to traumatise, particularly where help results in obligations to show gratefulness or shame and control becomes overpowering.

Thesis 2: The logic of case reconstruction aims to reveal realistic options for an autonomous lifestyle in practical Social Work.

The stylistic features of a case-reconstructive focus consist in showing that a dialectic context exists between "what is" (mode of existence) and "what could be" (options for the future). The logic of 
case reconstruction largely apply in that differentiated evaluation of a case is performed from different perspectives. The case-reconstructive process thus serves the purpose of offering a realistic insight into a life practice subject to crises and requiring help (cf. table 3 ).

Table 3

Perspectives of "case-reconstructive social work"

Perspective Activity

(1) Humans and society as the subject

Reconstruction of appearance and entity - of what is latent and what is manifest

(2) Constructive criticism of the 'given'

Comparison between the reconstructed situation with what is possible, between idea (target) and reality (actual).

Knowledge gained through reconstructing a case serves the purpose of enabling an examination of biographical processes, courses of action of a practice or institutional types of responses from the perspective of coping with crisis as well as staying true to a realistic evaluation of a case. A social worker who in light of this is introduced to the logic of "case-reconstructive Social Work", "must still get to know the factual situational principles of considerate social work action - e.g., assuming the clients' definitions of situations" (Schütze, 2002, p. 147). He can use case reconstruction as a tool to identify the biographical sources of meaning with regard to the case in question and to become aware of his own biographical traumatic dispositions (traumatic childhood experiences which appear in a present case in a structurally similar way). Case reconstruction must be used to reveal this during the case-handling process in the same way as paradoxes ${ }^{5}$ and typically sources or tendencies towards mistakes in professional work (cf. Schütze, 1997). A sober reconstruction of objective data, authentic materials for expression and biographical conditions - on both sides - in the relevant case problem enables new, structurally realistic options to be determined, which solidify the work cooperation. Once responsibility for oneself has been factually achieved in work, parenthood and citizenship, coinciding with the end of the moratorium of coping with the crises of adolescence, any autonomy already achieved generally takes effect. This "logic of autonomisation" in broader versions contrasts with the propagation of "lifelong learning", whose principles are structurally contrary to an autonomy already achieved.

\section{Thesis 3: "Case-reconstructive Social Work" serves the purpose of promoting autonomous thinking and action in the discipline and the profession.}

Autonomous thinking and action are based on the anthropological basis of freedom. In the battle to gain recognition, as described by Hegel, it becomes apparent that freedom is related to the ability of humans to cross the borders of self-preservation and having to choose to maintain one's freedom ${ }^{6}$. Language provides the means to achieve this. The method of objective hermeneutics make it possible to reconstruct this battle for recognition as well as the history of decisions (individual or collective choices) and to draw conclusions for Social Work. An interpretation may never be entirely complete, but it can reach a temporary end point if no further general or specific statements are possible - until a newly discovered context opens up a convincing reinterpretation. Identifying such a structure, which delineates a pattern of meaning with the "mode of existence of a meaning" according to Schleiermacher (2000), requires an act of methodically controlled understanding,

5 Schütze defines the paradoxes of prof. action as "difficulties and dilemmas in the work process, which cannot be undone or avoided, and in which the professional necessarily becomes enmeshed" (Schütze, 1992, p. 137).

6 "Hegel was the first to correctly present the relationship between freedom and necessity. For him, freedom is the insight into necessity" (Engels, 1990, p. 106). 
enabled not by empathy but by strictly methodical control and substantiality. The objective richness of meanings - revealed by the hermeneutic method of case reconstruction - opens up because subjective imagination is triggered early on in the cognitive process (relating to a life practice in crisis). This is required to enable interpretation and is provided by the theory of art. In this way, options to uncover what is new or "latent" are revealed. This is achieved through participation in an educational process which decrypts latent meaning - represented in case and in theories - using case reconstruction. The realisation of an objective meaning thus unfolds its effect step by step if discursive communication based on the material of expression occurs. For instance, this is essential when conceptualising a social diagnostic which requires as rich a data basis as possible and which if possible must take into account all perspectives affecting a case, situation or event - meaning a set of data about a social act. In this context, autonomous thinking and action are apparent in that reconstruction logic is asserted against the usual subsumption logic. Whereas the latter subsumes using theoretical terminology or commonly used definitions, the former analyses is based on sequence and aims to identify the laws which a case represents in its totality "with reference to readable, audible and visible symbols and markings" (Oevermann, 2002a, p. 23). Vicarious coping with crisis is to make the crisis process of child-raising and socialising individuals, which offers an opportunity to create autonomy in life practice, easier - as demonstrated. This assumes autonomous thinking and action on the part of the professional actors - these can be social workers or researchers who in the individual case act with the tradition of hermeneutic empirical science. The realisation of a typological core case, the reconstruction of further cases to expand and modify experience and the focus on structural generalisation logic in order to imagine an educational process whose future is characterised by the case structures of a specific life, are the contents and objectives of a case-reconstructive activity, which can commence its (Social) Work in life practice.

\section{References}

Adorno, T. W. (1969). Erziehung zur Mündigkeit. Vorträge u. Gespräche mit Hellmut Becker 19591969. Frankfurt Main: Suhrkamp.

Bock, T. (1986). Sozialarbeit/Sozialpädagogik. In Deutscher Verein für öffentliche und private Fürsorge (Ed.), Fachlexikon der Sozialen Arbeit (pp. 746-749). Frankfurt am Main: Suhrkamp.

Bourdieu, P. (1984). Die feinen Unterschiede. Kritik der gesellschaftlichen Urteilskraft. Frankfurt am Main: Suhrkamp.

Czarny, M., \& Marks, S. (2015). Tod und Trauer in der Heimerziehung. Stellvertretende Krisenbewältigung als Handlungsoption. Ibbenbüren: Münstermann Verlag.

Dollinger, B. (2006). Die Pädagogik der sozialen Frage. (Sozial-)pädagogische Theorie vom Beginn des 19. Jahrhunderts bis zum Ende der Weimarer Republik. Wiesbaden: VS Verlag.

Engelke, E. (1992). Soziale Arbeit als Wissenschaft. Eine Orientierung. Freiburg im Breisgau: Lambertus Verlag.

Engels, F. (1990). Anti-Dühring. In Engels, F., \& Marx, K. (Eds.), Werke. 10th edition, unaltered reprint of the 1st edition from 1962. Berlin: Dietz.

Kraimer, K. (2000). Die Fallrekonstruktion - Bezüge, Konzepte, Perspektiven. In K. Kraimer (Ed.), Die Fallrekonstruktion: Sinnverstehen in der sozialwissenschaftlichen Forschung (pp. 23-57).Frankfurt am Main: Suhrkamp.

Kraimer, K. (2012). Devianz-Pädagogik. Kinder und Jugendliche in Krisen. Ibbenbüren: Münstermann Verlag.

Kraimer, K. (2014). Fallrekonstruktive Soziale Arbeit. Ansätze, Methoden, Optionen. Einführung mit Glossar und Bibliografie. Ibbenbüren: Münstermann Verlag. 
Kraimer, K., \& Altmeyer, L. (2016). Sozialpädagogische Spannungsfelder und Herausforderungen in Hort und Ganztagsschule. In N. Neuß (Ed.), Kindheit in Hort und Ganztagsschule sozialpädagogische Herausforderungen. Berlin: Cornelsen Verlag.

Kraimer, K., \& Wyssen-Kaufmann, N. (2012). Die fallrekonstruktive Forschungswerkstatt - eine Option zur Förderung von Professionalität in der Sozialen Arbeit. In R. Becker-Lenz, S. Busse, G. Ehlert, \& S. Müller-Hermann (Eds.), Professionalität Sozialer Arbeit und Hochschule. Wissen, Kompetenz, Habitus und Identität im Studium Sozialer Arbeit (pp. 219-233). Wiesbaden: Springer VS.

Liebermann, S., \& Loer, T. (2009). Krisenbewältigung oder Verantwortungsdelegation? Analytische Anmerkungen zum Arbeitsbündnis in fallorientierter Beratung von Organisationen. Arbeits - und Industriesoziologische Studien, 2(1), 29-42.

Lüssi, P. (1991). Systemische Sozialarbeit. Praktisches Lehrbuch der Sozialberatung. Bern \& Stuttgart: Haupt Verlag.

Mollenhauer, K. (1959). Soziale Arbeit heute - Gedanken über ihre sozialen und ideologischen Voraussetzungen. In R. Merten (Ed.), Sozialarbeit - Sozialpädagogik - Soziale Arbeit: Begriffsbestimmungen in einem unübersichtlichen Feld (pp. 79-92). Freiburg im Breisgau: Lambertus.

Mollenhauer, K. (1988). Erziehungswissenschaft oder Sozialpädagogik/Sozialarbeit oder Das Pädagogische in der Sozialarbeit/Sozialpädagogik. Sozia/wissenschaftliche Literaturrundschau, 11(17), 53-58.

Niemeyer, C. (2012). Sozialpädagogik, Sozialarbeit, Soziale Arbeit - »klassische« Aspekte der Theoriegeschichte. In W. Thole (Ed.), Grundriss Soziale Arbeit (pp. 135-150). Wiesbaden: Springer VS-Verlag.

Oevermann, U. (1996). Theoretische Skizze einer revidierten Theorie professionalisierten Handelns. In A. Combe, \& W. Helsper (Eds.), Pädagogische Professionalität: Untersuchungen zum Typus pädagogischen Handelns (pp. 70-182). Frankfurt am Main: Suhrkamp.

Oevermann, U. (2000). Die Methode der Fallrekonstruktion in der Grundlagenforschung sowie der klinischen und pädagogischen Praxis. In K. Kraimer (Ed.), Die Fallrekonstruktion: Sinnverstehen in der sozialwissenschaftlichen Forschung (pp. 58-156). Frankfurt am Main: Suhrkamp.

Oevermann, U. (2002a). Die Methode der Fallrekonstruktion in der Grundlagenforschung sowie der klinischen und pädagogischen Praxis. In K. Kraimer (Ed.), Die Fallrekonstruktion: Sinnverstehen in der sozialwissenschaftlichen Forschung (pp. 58-156). Frankfurt am Main: Suhrkamp.

Oevermann, U. (2002b). Klinische Soziologie auf der Basis der Methodologie der objektiven Hermeneutik (Manifest der objektiv hermeneutischen Sozialforschung). Frankfurt am Main: Arbeitsgemeinschaft Objektive Hermeneutik e.V.

Oevermann, U. (2009). Die Problematik der Strukturlogik des Arbeitsbündnisses und der Dynamik von Übertragung und Gegenübertragung in einer professionalisierten Praxis von Sozialarbeit. In R. Becker-Lenz, S. Busse, G. Ehlert, \& S. Müller-Hermann (Eds.), Professionalität in der Sozialen Arbeit. Standpunkte - Kontroversen - Perspektiven (pp. 113-142). Wiesbaden: VS Verlag,.

Oevermann, U. (2013). Die Problematik der Strukturlogik des Arbeitsbündnisses und der Dynamik von Übertragung und Gegenübertragung in einer professionalisierten Praxis von Sozialarbeit. In R. Becker-Lenz, S. Busse, G. Ehlert, \& S. Müller-Hermann (Eds.), Professionalität in der Sozialen Arbeit. Standpunkte - Kontroversen - Perspektiven (pp. 119-148). 3rd revised edition. Wiesbaden: Springer VS.

Otto, H., \& Thiersch, H. (2011). Handbuch Soziale Arbeit. 4th edition. Munich: Reinhardt. 
Reyer, J. (2002). Kleine Geschichte der Sozialpädagogik. Individuum und Gemeinschaft in der Pädagogik der Moderne. Hohengehren: Schneider Verlag.

Schleiermacher, F. (2000). Texte zur Pädagogik. Frankfurt am Main: Suhrkamp.

Schütze, F. (1992). Sozialarbeit als »bescheidene« Profession. In B. Dewe, W. Ferchhoff, \& F. O. Radtke (Eds.), Erziehen als Profession: zur Logik professionellen Handelns in pädagogischen Feldern (pp. 132-169). Opladen: Leske und Budrich.

Schütze, F. (1997). Kognitive Anforderungen an das Adressatendilemma in der professionellen Fallanalyse der Sozialarbeit. In G. Jakob, \& H. Wensierski (Eds.), Rekonstruktive Sozialpädagogik. Konzepte und Methoden sozialpädagogischer Forschung und Praxis (pp. 39-60). Weinheim, Munich: Juventa.

Schütze, F. (2002). Supervision als ethischer Diskurs. In M. Kraul, W. Marotzki, \& C. Schweppe (Eds.), Biographie und Profession (pp. 135-164). Bad Heilbrunn: Verlag Julius Klinkhardt.

Schütze, F. (2014). Professionelles Handeln auf der Basis von Fallanalyse - Sozialarbeit als Profession. In M. Schwarz, W. Ferchhoff, \& R. Vollbrecht (Eds.), Professionalität: Wissen - Kontext. Sozialwissenschaftliche Analysen und pädagogische Reflexionen zur Struktur bildenden und beratenden Handelns (pp. 140-161). Bad Heilbrunn: Verlag Julius Klinkhardt.

Wigger, A. (2013). Der Aufbau eines Arbeitsbündnisses in Zwangskontexten-professionstheoretische Überlegungen im Licht verschiedener Fallstudien. In R. Becker-Lenz, S. Busse, G. Ehlert, \& S. Müller-Hermann (Eds.), Professionalität in der Sozialen Arbeit. Standpunkte - Kontroversen Perspektiven (pp. 149-165). 3rd revised edition. Wiesbaden: Springer VS.

\section{Further sources}

Räume für Bildung. Räume der Bildung - DgfE Congress 2016. (2015, September 16). Retrieved from http://www.dgfe2016.de

Politik der Verhältnisse - Politik des Verhaltens: Widersprüche der Gestaltung Sozialer Arbeit. (2015, September 16). Retrieved from http://www.bundeskongress-soziale-arbeit-2015.de 